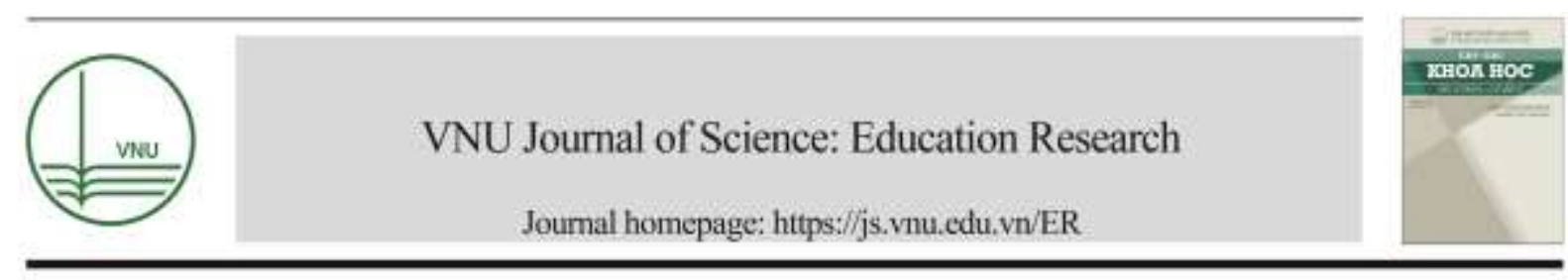

Original Article

\title{
Integrated Teaching Competency Framework for General Education Program: Suggestions and Recommendations for Natural Science Teachers
}

\author{
Vu Thi Thu Hoai* \\ VNU University of Education, 144 Xuan Thuy, Cau Giay, Hanoi, Vietnam
}

Received 15 November 2021

Revised 22 November 2021; Accepted 22 November 2021

\begin{abstract}
This article investigated the general structure of teaching competencies and integrated teaching competencies of natural science teachers in high school education, the actual situation of integrated teaching in Vietnam and some other countries in the world, and the designing of assessment templates to recognize difficulties of natural science teachers in integrated teaching. It is shown that natural science teachers are facing various challenges in integrated teaching: a lack of professional knowledge and skills in building integrated topics and teaching with this approach, problems in putting integrated teaching techniques into practice. On this foundation, the article presents a procedure for building an integrated teaching competency framework for natural science teachers, then proposes such a framework. This framework consists of 4 competencies and ten criteria with detailed indicators. Natural science teachers can use this framework to develop tools (checklists, rating scales, or questionnaires) to assess their integrated teaching quality and their "colleagues", henceforth fostering their competencies as required by the General Education Program.
\end{abstract}

Keywords: Teaching competencies, integrated teaching competency framework, natural science teachers, high school education.

\section{Introduction}

The competency-based curriculum covers the expected learning outcomes instead of regulating detailed teaching content. Several scientists have recognized that integrated teaching has an important role in competency-based teaching.

\footnotetext{
* Corresponding author.

E-mail address: hoaivtt@vnu.edu.vn

https://doi.org/10.25073/2588-1159/vnuer.4609
}

According to them, the integrated approach is developed based on positive notions of teaching and learning. Integrated teaching is an idea, a principle, and a perspective investigated and recognized by many educators. It's a helpful tool to combine knowledge into a uniform and integrated form. Authors J. A. Beane and $X$. Roegiers have pointed out the disadvantages of the subject-based curriculum and confirmed the role of integrated teaching as a method to help students develop their competencies [1,2]. 
Victoria and Paul researched the effects of integrated teaching with an approach of modelling on learning styles and learning outcomes of students in Chemistry [3]; The research confirmed that interest, learning outcomes, and knowledge of students in Chemistry is long-lasting. To make the integrated teaching approach successful, the teaching competencies of teachers must be paid attention to. This factor is a challenge concerned by educators. Luft and Hewson suggested that teachers in different subjects will have different skills or competencies in integrated teaching. The success of any teaching method depends on the skills of teachers (in selecting knowledge aspects, instruction delivering techniques, pedagogical content) [4].

Besides, Harrell stated the shortage of teachers to be a significant obstacle in teaching integrated science in the US [5]. Diaconu and others pointed out that the education system of many countries encountered difficulties in the integrated teaching of science subjects [6]. In Australia, the existence of traditional assessment models, pressure on traditional learning criteria from parents, subject-based teaching skills, limited time for instructions, a lack of materials on integrated teaching, a lack of competent teachers and cooperation from school and colleagues have all negatively affected the implementation of the integrated teaching approach [7]. In this meaning, teachers in natural subjects must be trained to do the integrated teaching. Webster, Peletier Joy and Cooper Maxine have done research on integrated teaching methods in training teachers and suggested the following: teachers should thoroughly understand the theory as well as the application of the integrated teaching model; approach the implementation of integrated teaching (through offline or online instructions) $[8,9]$. Hobbs claimed that secondary school teachers usually engage themselves with a particular subject; all the knowledge, skills, and teaching competencies acquired during the training and on the job are for that particular subject only [10]. These show that it is not easy for natural science teachers to change their nature and become general teachers who can teach all subjects.

We can see that the integrated teaching skills of teachers are a critical part of the teaching competency framework. Many researchers have identified this framework; it comes to life in various forms and levels of development depending on each field. In education, a widely used article defined the teaching competency framework as: The framework of teacher competencies consists of a number of aspects, including knowledge, skills and attitude in teachers, allowing educators to do their teaching work the most effectively [11]. Thus, this framework helps learners identify expected learning outcomes, helps teachers select effective content, teaching methods, and assessment methods to facilitate learners to achieve their targets. The integrated teaching competency framework in Viet Nam has been an issue of interest to several scientists and educators. The authors in the work of [12-14] have studied and assessed the actual competence in integrated teaching of students in teacher training courses and of high school teachers in the context of education reform with the approach of competency development for learners; studied and suggested an integrated teaching competency framework for students in teacher training with three elements: the competence in the general understanding of integrated teaching, the competence in designing and teaching integrated topics, and the competence in testing and assessing the teaching of integrated topics. Recently, Nguyen Thi Thuy Trang et al., has proposed an integrated teaching competency framework STEM for students in teacher training of chemistry major with four elements and 12 criteria, helping students orientate and develop their learning motive to achieve learning outcomes [15].

Currently, all high school teachers in Viet Nam have been trained to specialize in a 
particular subject. Therefore, the lack of knowledge when it comes to integrated teaching must be paid more attention to. This study focuses on the competency of teachers in subjects of Physics, Chemistry and Biology (hereafter referred to as natural science teachers). These teachers have been teaching a specific subject and have remained a particular approach to achieve the learning outcomes expected in that subject for a long time. And so, 'it's only natural that they have different perspectives in terms of teaching skills and the importance of subjects, including natural sciences. Consequently, the requirement for integrated teaching is a tremendous challenge for these teachers. The actual situation of integrated teaching in high schools shows that the awareness of the importance or benefits of integrated teaching is a vital part of teaching competencies of teachers; the application of integrated teaching to achieve learning outcomes with the competency development approach for students is encountering a lot of difficulties (from selecting core content of subjects to build up integrated topics, to effectively using this approach to instruct and evaluate students and so on) [16]. Based on general studies about integrated teaching competence of high school teachers: the concept of teaching competencies and integrated teaching competencies, the structure of integrated teaching competencies as required by the National Curriculum 2018, the assessment of the actual situation of integrated teaching, along with the survey of 133 natural science teachers on factors affecting integrated teaching, this articles suggests principles and the procedure to develop an integrated teaching competency framework, then build up the integrated teaching competency framework for natural science teachers. This framework supports teachers to foster teaching capacity to meet the requirements of innovation of teaching methods to develop learner capacity and provides requirements for each criterion, thus will act as the foundation for teachers to evaluate, develop and improve their competence of integrated teaching, at the same time develop their professional knowledge in their career path.

\section{Research Overview}

\subsection{Integrated Teaching Competence for Natural Science Teachers}

Competence is a term widely used in various contexts. There are many definitions of competence and competency. According to De Ketele: "A competence is a set of organized capacities (activities), which action contents in a given category of situations in order to solve a problem" [17]. In this definition, competence is described as an ability to carry out a specified task or activity to pre-determined standards of attainment. According to De Bueger-Vander Borght C: "competence refers to a state of being well-qualified to perform an activity, task or job function. When a person is competent to do something, they achieve a state of competence that is recognizable and verifiable to a particular community of practitioners. A competency, then, refers to the way that a state of competence can be demonstrated to the relevant community" [18]. Pellerey has reconstructed the evolution of the competency concept during the last years; now it means not only the mastery of knowledge and methods, or the ability to manage them, but also the ability to integrate different kinds of knowledge and to use them synergically [19]. To be competent in a certain area implies the ability to mobilize one's knowledge and transform it into concrete doing: competency is an individual characteristic and is built (through self-experience and formation) in a given field and a given area of problems. DeSeCo argues: "Competence is the combination of the mindset, skills, and attitudes that are available or potentially learnable by an individual or organization to successfully perform tasks" [20]. Competence is a system of human abilities to flexibly, creatively, and effectively perform certain tasks and activities.

Teaching competence is the ability to apply the teacher's knowledge, skills, and attitudes to successfully carry out the task of orienting 
learners to self-own knowledge and form personal competencies.

Integrated teaching competence is the ability to apply the knowledge of integrated teaching to analyze the possibility of teaching an integrated topic, a lesson, or a chapter in a subject; it's also the ability to design an integrated teaching topic and successfully implement it [21].

Integrated teaching competence of natural science teachers. With concepts and definitions mentioned above, this article identifies five elements of competencies, including:

+ Knowledge of integrated teaching orientation;

+ Professional knowledge of natural sciences to develop integrated topics;

+ The skill to apply the theoretical basis of integrated teaching to analyze, summarize and compare basic professional knowledge of teachers to the content of natural science subjects to develop integrated topics;

+ The competence in successfully implementing the learning plan with developed integrated topics to help students develop their competencies;

+ The competence in assessing the teaching of integrated topics (competency-based assessment of students, of themselves, and of colleagues).

In the light of this study, identifying elements of integrated teaching is critical for suggesting a teaching framework, as this is the foundation to build up performance factors as well as criteria, indicators, and levels of achievement of each criterion. This is also the basis to develop a rating scale in competency-based teaching.

\subsection{Principles of Building an Integrated} Teaching Competency Framework for Natural Science Teachers

Principle 1. Scientific: the integrated teaching competency framework for natural science teachers must be based on the theoretical basis of integrated teaching, competences in general and integrated teaching competencies in particular [20], and regulations on professional standards for teachers of general education institutions of Ministry of Education and Training [24]. At the same time, the framework must be logical, coherent, accurate, scientific, and related to elements of competencies and their corresponding indicators/criteria.

Principle 2. Objective: the framework must be clear. Criteria must adequately reflect the development of integrated teaching competencies (this article identifies five elements of those competencies) and be suitable with the target of developing general competencies for high schoolers in subjects of natural sciences.

Principle 3. Practical: the framework must come from the understanding, analysis, and assessment of the actual situation in the integrated teaching of natural science subjects, and from difficulties faced by teachers; suggested criteria to be achieved to solve those problems, ensuring that professional competencies of teachers meet the requirements of the 2018 General Education Program [23].

Principle 4. Comprehensive: each element of competencies consists of criteria from which levels of achievement are developed with specific performance. This is the basis for teachers to assess their teaching competencies as well as their "colleagues". The integrated teaching competency framework for natural science teachers must be competency-based assessment.

Principle 5. Feasible: the framework must be a tool for teachers to refer to and compare with their current teaching competencies; levels of achievement must be specific, clear, and measurable.

\section{Methodology}

\subsection{Survey on Difficulties of Integrated Teaching for Natural Science Teachers}

To get a practical basis for suggesting an integrated teaching competency framework for natural science teachers, this study surveyed natural science teachers at high schools in Northern Vietnam during the school year 2020-2021 to obtain a practical basis for 
developing an integrated teaching competency framework for this teacher group. We employed the Google Forms survey approach, which is useful because the teachers come from various schools in Northern Vietnam. Our sample of 133 science teachers is drawn from more than 30 high schools. 50.4 percent of them work in city centers, whereas 44.3 percent of responders live in the suburbs. Simultaneously, 5.3 percent of them work in mountainous locations. The survey focuses on the feedback of teachers regarding difficulties and how they affect the integrated teaching with the main points as below:

i) The content of the integrated teaching;

ii) The interknowledge of natural sciences;

iii) The development of integrated topics for subjects of natural sciences;

iv) The use of active teaching methods in integrated teaching.

The survey is designed on Google Form and randomly sent to natural science teachers, with 133 responses as presented in Table 1 and Table 2.

Table 1. General information of respondents (natural science teachers)

\begin{tabular}{|l|l|l|}
\hline $\begin{array}{l}\text { Teaching } \\
\text { subjects: }\end{array}$ & Number (N) & Percentage (\%) \\
\hline Physics & 17 & 12.8 \\
\hline Chemistry & 74 & 55.6 \\
\hline Biology & 26 & 19.5 \\
\hline $\begin{array}{l}\text { Other natural } \\
\text { sciences }\end{array}$ & 16 & 12 \\
\hline Total & 133 & 100 \\
\hline
\end{tabular}

Table 2. Locations of teacher's work

\begin{tabular}{|l|l|l|}
\hline Areas & Number $(\mathrm{N})$ & Percentage $(\%)$ \\
\hline City centers & 67 & 50.4 \\
\hline Suburbs & 59 & 44.4 \\
\hline Mountainous & 7 & 5.3 \\
\hline Total & 133 & 100.0 \\
\hline
\end{tabular}

3.2. Process of Building an Integrated Teaching Competency Framework for Natural Science Teachers

Based on general studies about integrated teaching competence of high school teachers, the practical basis on difficulties of integrated teaching for natural science teachers. This article suggests the process of building an integrated teaching competency framework for natural science teachers, it includes six steps:

Step 1. Study materials of teaching competencies integrated teaching competencies of high school teachers and teaching with competency development approach for students. Pay attention to general and specific competencies for each subject in teaching individual subjects and integrated natural sciences.

Step 2. Identify elements of competencies and corresponding criteria for integrated teaching.

Step 3. Develop a table describing the criteria/performance of each competence in detail according to the rating scale.

Step 4. Consult expert advice, survey opinions of teachers regarding the structure and performance of integrated teaching competencies.

Step 5. Adjust, modify, and complete the framework and the criteria for competency performance in integrated teaching of natural science teachers.

Step 6. Check, evaluate and complete the integrated teaching competency framework for natural science teachers.

\section{Results and Discussions}

\subsection{Difficulties Faced by Natural Science Teachers in Integrated Teaching}

In order to obtain this information of difficulties or challenges faced by teachers in integrated teaching, this study has investigated materials and articles regarding the actual situation of integrated teaching in some countries such as France, China, and Viet Nam. Those materials have assessed the challenges that specialized teachers must face in the integrated teaching of natural science subjects 
(Physics, Biology and Technology) along with solutions to proceed with the integrated teaching [22]. Challenges in integrated teaching faced by Chinese teachers have shown factors affecting the competencies of specialized teachers in integrated teaching [23]. The actual situation of Chemistry teaching in Vietnamese high schools has stated that natural science teachers encounter lots of difficulties in integrated teaching [16], etc. The survey results showed that a large number of teachers confirmed they had difficulties implementing integrated teaching in Table 3.

Table 3. Suggested difficulties faced by natural science teachers in integrated teaching

\begin{tabular}{|c|c|c|c|}
\hline & $\begin{array}{c}\text { Selected } \\
\text { option }\end{array}$ & $\mathrm{N}$ & Percentage $(\%)$ \\
\hline \multirow{7}{*}{$\begin{array}{l}\text { In your } \\
\text { opinion, is } \\
\text { integrated } \\
\text { teaching } \\
\text { difficult? }\end{array}$} & Agree & 67 & 50.4 \\
\hline & $\begin{array}{l}\text { Strongly } \\
\text { agree }\end{array}$ & 10 & 7.5 \\
\hline & $\begin{array}{l}\text { Strongly } \\
\text { disagree }\end{array}$ & 14 & 10.5 \\
\hline & Disagree & 42 & 31.6 \\
\hline & Total & 133 & 100.0 \\
\hline & Mean & \multicolumn{2}{|r|}{2.55} \\
\hline & SD & \multicolumn{2}{|r|}{0.78} \\
\hline
\end{tabular}

By going through theoretical basis and practical assessment, this article identifies 10 points of difficulties natural science teachers face and asks for their opinions regarding the effect of those difficulties on their teaching competencies. The result is presented in Table 4.

From what is shown in Table 4, it can be seen that the main problem with teachers is a lack of knowledge of integrated teaching. Only $2.3 \%$ of the respondents think that the overall knowledge of integrated teaching has no significant effect on their job. The factor of no initial training of integrated teaching seems to have considerable impacts on teachers' teaching quality (with $46.6 \%$ of medium effect and $12.8 \%$ of strong effect). These figures indicate the importance of theoretical knowledge of integrated teaching. Besides, up to $45.9 \%-47.4 \%$ of respondents says that they must spend extra time obtaining more newly required knowledge of other natural sciences or have little knowledge of how to use positive teaching methods in integrated teaching, which affects their teaching competenciesThe survey result also reflects the actual situation of the issue: teachers who can teach all-natural science subjects are not yet available, as they are trained to be specialized ones. They have long been practising their job in this manner, with particular skills and knowledge for their specific subject. It can be stated that this is the practical basis for the article to suggest principles, a procedure to develop, and an integrated teaching competency framework for natural science teachers.

Table 4. Feedback of teachers in terms of difficulties and their effects on integrated teaching

\begin{tabular}{|c|c|c|c|c|c|c|c|c|c|}
\hline No & \multicolumn{2}{|l|}{ Items } & $\begin{array}{l}\text { No } \\
\text { effect }\end{array}$ & $\begin{array}{l}\text { Slight } \\
\text { effect }\end{array}$ & $\begin{array}{l}\text { Medium } \\
\text { effect }\end{array}$ & $\begin{array}{l}\text { Strong } \\
\text { effect }\end{array}$ & Total & SD & Mean \\
\hline \multirow{2}{*}{1} & \multirow{2}{*}{$\begin{array}{l}\text { Poor official } \\
\text { materials on teaching } \\
\text { integrated topics }\end{array}$} & $\mathrm{N}$ & 3 & 57 & 48 & 25 & 133 & \multirow{2}{*}{0.79} & \multirow{2}{*}{2.71} \\
\hline & & $\%$ & 2.3 & 42.9 & 36.1 & 18.8 & 100.0 & & \\
\hline \multirow{2}{*}{2} & \multirow{2}{*}{$\begin{array}{l}\text { Lack of training on } \\
\text { teaching integrated } \\
\text { topics }\end{array}$} & $\mathrm{N}$ & 6 & 52 & 43 & 32 & 133 & \multirow{2}{*}{0.87} & \multirow{2}{*}{2.76} \\
\hline & & $\%$ & 4.5 & 39.1 & 32.3 & 24.1 & 100.0 & & \\
\hline \multirow{2}{*}{3} & \multirow{2}{*}{$\begin{array}{l}\text { Lack of training on } \\
\text { ICT in teaching }\end{array}$} & $\mathrm{N}$ & 16 & 45 & 52 & 20 & 133 & \multirow[t]{2}{*}{0.89} & \multirow{2}{*}{2.57} \\
\hline & & $\%$ & 12.0 & 33.8 & 39.1 & 15.0 & 100.0 & & \\
\hline
\end{tabular}




\begin{tabular}{|c|c|c|c|c|c|c|c|c|c|}
\hline \multirow{2}{*}{4} & \multirow{2}{*}{$\begin{array}{l}\text { Integrated teaching is } \\
\text { currectly optional for } \\
\text { subjects of natural } \\
\text { sciences in high } \\
\text { school education }\end{array}$} & $\mathrm{N}$ & 14 & 59 & 53 & 7 & 133 & \multirow{2}{*}{0.75} & \multirow{2}{*}{2.40} \\
\hline & & $\%$ & 10.5 & 44.4 & 39.8 & 5.3 & 100.0 & & \\
\hline \multirow{2}{*}{5} & \multirow{2}{*}{$\begin{array}{l}\text { Less initial or } \\
\text { regular training } \\
\text { on integrated } \\
\text { teaching }\end{array}$} & $\mathrm{N}$ & 9 & 45 & 62 & 17 & 133 & \multirow{2}{*}{0.79} & \multirow{2}{*}{2.65} \\
\hline & & $\%$ & 6.8 & 33.8 & 46.6 & 12.8 & 100.0 & & \\
\hline \multirow{2}{*}{6} & \multirow{2}{*}{$\begin{array}{l}\text { Poor specific } \\
\text { procedure introduced } \\
\text { for developing } \\
\text { integrated topics }\end{array}$} & $\mathrm{N}$ & 5 & 45 & 57 & 26 & 133 & \multirow[t]{2}{*}{0.80} & \multirow{2}{*}{2.78} \\
\hline & & $\%$ & 3.8 & 33.8 & 42.9 & 19.5 & 100.0 & & \\
\hline \multirow[b]{2}{*}{7} & \multirow{2}{*}{$\begin{array}{l}\text { Extra time for obtain } \\
\text { new knowledge for } \\
\text { other subjects of } \\
\text { natural sciences }\end{array}$} & $\mathrm{N}$ & 8 & 39 & 56 & 30 & 133 & \multirow{2}{*}{0.85} & \multirow[b]{2}{*}{2.81} \\
\hline & & $\%$ & 6.0 & 29.3 & 42.1 & 22.6 & 100.0 & & \\
\hline \multirow[b]{2}{*}{8} & \multirow{2}{*}{$\begin{array}{l}\text { More knowledge } \\
\text { required for } \\
\text { reality-related } \\
\text { aspects of } \\
\text { natural sciences }\end{array}$} & $\mathrm{N}$ & 6 & 43 & 61 & 23 & 133 & \multirow[b]{2}{*}{0.79} & \multirow[b]{2}{*}{2.76} \\
\hline & & $\%$ & 4.5 & 32.3 & 45.9 & 17.3 & 100.0 & & \\
\hline \multirow{2}{*}{9} & \multirow{2}{*}{$\begin{array}{l}\text { Extra time for } \\
\text { developing } \\
\text { integrated topics }\end{array}$} & $\mathrm{N}$ & 6 & 43 & 51 & 33 & 133 & \multirow{2}{*}{0.85} & \multirow{2}{*}{2.83} \\
\hline & & $\%$ & 4.5 & 32.3 & 38.3 & 24.8 & 100.0 & & \\
\hline \multirow{2}{*}{10} & \multirow{2}{*}{$\begin{array}{l}\text { Positive teaching } \\
\text { methods and } \\
\text { techniques are } \\
\text { required for } \\
\text { integrated teaching }\end{array}$} & $\mathrm{N}$ & 8 & 44 & 63 & 18 & 133 & \multirow{2}{*}{0.78} & \multirow{2}{*}{2.68} \\
\hline & & $\%$ & 6.0 & 33.1 & 47.4 & 13.5 & 100.0 & & \\
\hline
\end{tabular}

\subsection{Integrated Teaching Competency Framework for Natural Science Teachers}

Upon the structure of the integrated teaching competency framework for natural science teachers, theories, and the actual situation of integrated teaching, the principles and procedure for developing the competency framework, the article suggests a framework with four elements and 10 specific criteria described in Table 5.

The integrated teaching competency framework for natural science teachers is designed with competency development for learners. The framework supports teachers in identifying knowledge, skills and competencies required for effective teaching of integrated topics. It also helps students select content, teaching methods, and assessment techniques to help learners achieve learning outcomes. However, each natural science teacher will use this framework in a way appropriate to particular requirements of their professional field, and may add or adjust some criteria and indicators to develop a personal rating scale for their teaching competencies, which meets the requirements of professional knowledge and can be observed and measured.

Compared to professional competency framework for teachers, teaching competency framework for students in educational 
institutions [25], and the integrated teaching framework for STEM investigated by other authors [15], this framework requires natural science teachers to thoroughly understand and manage the knowledge of natural sciences related to their specialized science; make a matrix of core content for the specialized science and related knowledge to develop integrated topics; know how to cooperate with other natural science teachers in developing and teaching integrated topics, and build a teaching process for integrated topics with an online or offline method in the context of COVID-19 pandemic, etc.

Table 5. Integrated teaching competency framework for natural science teachers

\begin{tabular}{|c|c|c|}
\hline Competencies & Criteria & Indicators \\
\hline \multirow{2}{*}{$\begin{array}{l}\text { 1. Specialized } \\
\text { competence on a } \\
\text { particular science } \\
\text { and natural } \\
\text { sciences }\end{array}$} & $\begin{array}{l}\text { 1.1. Master and } \\
\text { manage the knowledge } \\
\text { of the subject of } \\
\text { specialized natural } \\
\text { science }\end{array}$ & $\begin{array}{l}\text { - List of main integrated topics based on the specialized and } \\
\text { specific content subject. } \\
\text { - Implication specific principles, methods, and } \\
\text { techniques towards the specialized subject teaching. } \\
\text { - Implication specific knowledge/theories to explain and solve } \\
\text { practical issues related to the specialized subject. }\end{array}$ \\
\hline & $\begin{array}{l}\text { 1.2. Master and apply } \\
\text { the knowledge of } \\
\text { natural sciences related } \\
\text { to the specialized } \\
\text { subject }\end{array}$ & $\begin{array}{l}\text { - List of main related knowledge. } \\
\text { - Implication the knowledge of natural sciences to foster, } \\
\text { explain nature, and solve practical issues related to the } \\
\text { specialized subject. }\end{array}$ \\
\hline \multirow{4}{*}{$\begin{array}{l}\text { 2. Competence } \\
\text { in building } \\
\text { integrated topics } \\
\text { for natural } \\
\text { sciences }\end{array}$} & $\begin{array}{l}\text { 2.1. Master and update } \\
\text { on integrated teaching }\end{array}$ & $\begin{array}{l}\text { - List of main the basic theory of integrated teaching. } \\
\text { - Apply theories of integrated teaching to develop integrated } \\
\text { topics for subjects of natural sciences. }\end{array}$ \\
\hline & $\begin{array}{l}\text { 2.2. Make an } \\
\text { integrated content } \\
\text { matrix for natural } \\
\text { sciences }\end{array}$ & $\begin{array}{l}\text { - Implication teaching goals and topics with a competency } \\
\text { development approach. } \\
\text { - Identify core content of the specialized science and related } \\
\text { natural sciences to develop integrated topics. } \\
\text { - Make a core-content matrix of the specialized science and } \\
\text { related natural sciences. }\end{array}$ \\
\hline & $\begin{array}{l}\text { 2.3. Determine } \\
\text { necessary information } \\
\text { to develop integrated } \\
\text { topics according to the } \\
\text { core-content matrix }\end{array}$ & $\begin{array}{l}\text { - Select suitable and effective methods, tools, and formats for } \\
\text { teaching integrated topics. } \\
\text { - Determine an appropriate method for organizing learning } \\
\text { activities for students. } \\
\text { - Build teaching processes as pre-determined by the core- } \\
\text { content matrix of specialized subjects and natural sciences. }\end{array}$ \\
\hline & $\begin{array}{l}\text { 2.4. Show cooperation } \\
\text { with other teachers in } \\
\text { other natural sciences }\end{array}$ & $\begin{array}{l}\text { - Identify duties and assign to team members to develop and } \\
\text { teach integrated topics. } \\
\text { - Show the capacity of cooperation and effective teamwork in } \\
\text { developing and teaching integrated topics in natural sciences. }\end{array}$ \\
\hline $\begin{array}{l}\text { 3. Competence in } \\
\text { integrated } \\
\text { teaching of } \\
\text { natural sciences } \\
\text { with the approach }\end{array}$ & $\begin{array}{l}\text { 3.1. Organize activities } \\
\text { for teaching integrated } \\
\text { topics meeting the } \\
\text { requirements for } \\
\text { developing }\end{array}$ & $\begin{array}{l}\text { - Organize appropriate learning activities for students } \\
\text { according to the integrated topics. } \\
\text { - Use a variety of teaching methods and tools in teaching } \\
\text { integrated topics with the competency development approach. } \\
\text { - Organize and manage the class, create an effective learning }\end{array}$ \\
\hline
\end{tabular}




\begin{tabular}{|c|c|c|}
\hline $\begin{array}{l}\text { of competency } \\
\text { development for } \\
\text { students }\end{array}$ & $\begin{array}{l}\text { competencies for } \\
\text { students } \\
\text { 3.2. Implement the } \\
\text { teaching process with } \\
\text { different methods: } \\
\text { online or offline }\end{array}$ & $\begin{array}{l}\text { environment whether online or offline (Blended Learning, } \\
\text { Moodle, Zoom, Google Meet, etc.) during and after the lesson. }\end{array}$ \\
\hline $\begin{array}{l}\text { 4. Assessment } \\
\text { competence in } \\
\text { integrated } \\
\text { teaching of } \\
\text { natural sciences }\end{array}$ & $\begin{array}{l}\text { 4.1. Select and } \\
\text { combine assessment } \\
\text { techniques in teaching } \\
\text { integrated topics to } \\
\text { evaluate teaching } \\
\text { outcomes against the } \\
\text { requirements for } \\
\text { competency } \\
\text { assessment } \\
\text { 4.2. Suggest methods } \\
\text { for improving the } \\
\text { teaching process }\end{array}$ & $\begin{array}{l}\text { - Develop criteria and tools for competency assessment } \\
\text { according to teaching activities designed in each topic/theme. } \\
\text { - Regularly and effectively assess as required by principles and } \\
\text { requirements for developing integrated teaching competencies. } \\
\text { - Suggest methods for adjusting and reinforcing the assessment } \\
\text { in the process of developing and teaching integrated topics. } \\
\text { - Adjust teaching activities accordingly to the requirements for } \\
\text { teaching with a competency development approach. }\end{array}$ \\
\hline
\end{tabular}

\section{Conclusion}

When referring to the purposes and tasks of the research, this article has summarized theories on competencies and competencies for integrated teaching of teachers; investigated and evaluated the importance of integrated teaching in training and developing competencies for learners in the work of other researchers, both locally and internationally; investigated the actual situation of teaching specialized sciences to assess challenges faced by teachers in teaching integrated topics of natural science to make a concrete base for the research. Henceforth, the article identifies elements of integrated teaching competencies, suggest principles and procedure for developing an integrated teaching competency framework. Each criterion must be developed with indicators and specific levels to maximize the role of the framework in developing professional competencies for teachers. Therefore, the integrated teaching framework will be a foundation for teachers to refer to and assess their teaching skills, then make a corresponding plan to improve their knowledge and skills to practice and adjust the learning process in order to achieve teaching outcomes of developing competencies for students, meeting the requirements of teaching competencies for teachers in the General Education Program.

\section{References}

[1] J. A. Beane, Curriculum Integration: Designing the Core of Democratic Education, New York: Columbia University, Teachers College Press, 1997.

[2] X. Roegiers, Department of Integrated Pedagogy or How to Develop Competencies in Schools, Education Publishing House, 1996.

[3] F. F. Victoria, A. E. Paul, Enhancing Students' Achievement, Interest and Retention in Chemistry through an Integrated Teaching/Learning Approach. Journal of Education, Society and Behavior Science, Vol. 4, No. 12, 2014, pp. 653-1663.

[4] J. A. Luft, P. W. Hewson, Research on Teacher Professional Development Programs in Science, In S. K. Abell, N. Lederman (Eds.), Handbook of Research in Science Education, NY: Routledge, 2014, pp. 889-909.

[5] P. E. Harrell, Teaching an Integrated Science Curriculum: Linking Teacher Knowledge and Teaching Assignments, Issues in Teacher Education, Vol. 19, No. 1, 2010, pp. 145-165.

[6] C. Coggi, La Valutazione Delle Competenze, in C. Coggi and A. Notti (Eds.), Docimologia, Pensa-multimidia, Lecc, 2002, pp. 56-90.

[7] D. V. Diaconu, J. Radigan, M. Suskavcevic, C. Nichol, A multi-year Study of the Impact of the Rice Model Teacher Professional Development on Elementary Science Teachers, International Journal 
of Science Education, Vol. 34, No. 6, 2012, pp. 855-877.

[8] G. J. Venville, J. Wallace, L. J. Rennie, J. A. Malone, Curriculum Integration: Eroding the High Ground of Science as a School Subject, Studies in Science Education, Vol. 37, No. 1, 2002, pp. 43-83.

[9] J. R. Webster, The Implementation of an Integrated Approach to Teacher Training, British Journal of Teacher Education, Vol. 1, No. 2, 175, pp. 143-150.

[10] P. Joy, C. Maxine, Teacher Education: an Integrated Approach, South Pacific Journal of Teacher Education, Vol. 19, No. 1, 11, pp. 69-76.

[11] L. Hobbs, Examining the Aesthetic Dimensions of Teaching: Relationships between Teacher Knowledge, Identity and Passion, Teaching and Teacher Education, Vol. 28, 2012, pp. 718-727.

[12] E. Commission, Supporting Teacher Competence Development for better Learning Outcomes: Brussels: European Commission, 2013.

[13] D. H. Tra, Integrated Teaching Research: The Requirements Set in the Formulation, Selection of Content, and Organization of Teaching, Hanoi National Journal of University Science: Education Studies, Vol. 31, No. 1, 2015, pp. 44-51.

[14] D. T. T. An, T. T. Ninh, Develop an Integrated Teaching Capacity Framework for Chemistry Pedagogical Students, Journal of Science, Hanoi University of Education, Vol. 61, No. 6, 2016, pp. 79-86.

[15] V. T. T. Hoai, Fostering Integrated Teaching Capacity for Students in Chemistry Education at VNU University of Education, The $1^{\text {st }}$ International Conference on Innovation of Teacher Education, 2019, pp. $209-219$.

[16] N. T. T. Trang, D. T. Oanh, P. T. Binh, STEM Integrated Teaching Capacity Framework for Chemistry Pedagogy Students, HNUE Journal of science, Vol. 65, No. 4, 2020, pp. 177-184. https://doi.org/10.18173/2354-1075.2020-0068.

[17] V. T. T. Hoai, Reality and Measures for Developing Integrated Teaching Capacity for High School Chemistry Teachers, VNU Journal of Science: Education Research, Vol. 36, No. 2, 2020, pp. 17-26.

[18] D. Ketele, L'évaluation des Acquis Scolaires: Quoi? Pourquoi? Pour quoi? Cited by Roegiers X. (2000)
Une Pédagogie de L'intégration, Compétences et Intégration des Acquis Dans L'enseignement. Bruxelles, De Boeck, 1996, pp. 128.

[19] D. B. Vander, C. Borght, L'épistémologie Dans la Pratique de la Classe? Actes des XVIIièmes Journées Internationales sur la Communication, L'Education et la Culture Scientifiques et Techniques Chamonix: A. Giordan, J. L. Martinand, 1995, pp. 193-196.

[20] M. Pellerey, Sul Concetto di Competenza ed in Particolare di Competenza Sul Lavoro (Montedoro C. Ed.) Dalla Pratica Alla Teoria Per la Formazione: un Percorso di Ricerca Epistemologica, Franco Angeli, Milano, 2001, pp. 18-35.

[21] DeSeCo, Education - Lifelong Learning and the Knowledge Economy: Key Competencies for the Knowledge Society, In: Proceedings of the DeSeCo Symposium, Stuttgart, 2002.

[22] Ministry of Education and Training - MOET, Circular on Professional Standards for Teachers of High school Institution, 2012 (in Vietnamese).

[23] Ministry of Education and Training, General Education Program, Enclosed with Circular 32/2018 /TT-BGDDT, Hanoi, 2018.

[24] Maryline Coquide, Corinne Fortin, Christophe Lasson, Integrated Teaching of science and Technology in France, Paper presented at European Science Education Research Association, Lyon, France, 2012, pp. 46 -52.

[25] D. Sun, Z. H. Wang, W. T. Xie, C. C. Boon, Status of Integrated Science Instruction in Junior Secondary Schools of China: An Exploratory Study, International Journal of Science Education, Vol. 36, No. 5, 2014, pp. 808-838, https://doi.org/10.18173/23541075.2020-0103 10.1080/09500693.2013.829254.

[26] Ministry of Education and Training, Regulations on Professional Standards for Teachers of General Education Institutions, Enclosed with Circular 20/2018/TT-BGDDT, Hanoi, 2018.

[27] N. C. Khanh, D. T. Oanh, N. T. Hue, N. V. B. Hien, V. T. Son, N. V. Quang, Developing Standards for Learning Outcomes for Teacher Training Courses in Universities of Education. HNUE Journal Of Science Educational Sciences, Vol. 65, No. 9, 2020, pp. 164-179, https://doi.org/10.18173/2354-1075.2020-0103. 